\title{
LEGAL FRAMEWORK TRANSFORMATION TOWARDS EUROPEAN BANKING INTEGRATION
}

\author{
Associate professor Mihaela TOFAN ${ }^{1}$
}

\begin{abstract}
The paper analyzes recent EU actions in order to develop banking regulation towards having a real and operational banking union. The role and the present policy of the ECB is also addressed. EU banking priorities are presented, emphasizing the transformation imposed by the global financial crises and the recent cooperation among member states of the union. The interconnection banking-fiscal union is also approached, concluding on the mandatory steps to be taken in order to have a real support of the legal framework.
\end{abstract}

Keywords: financial and banking integration, reform the legal framework, proposals for law ferenda

JEL Classification: K22, K33

\section{Introduction}

The development of the financial crisis in the European Union area and the particular situation of Greece showed that the system of institutions to support the banking union is precarious and needs significant changes. The global crisis showed the need to reform banking regulations in the sphere of EU law, differences between national legal systems of the Member States resulting in postponement of the banking union accomplishment and limiting the effectiveness of monetary union. In this context, the need for rule of law, which is common for all Member States and is able to regulate banking and credit institutions is fully justified. Member of the executive and legislative authorities have formulated, proposed, and adopted measures to reform national banking systems in response to the global financial crisis.

\section{Regulatory measures for the cohesion of the EU banking system}

Banking law is part of domestic law of each state. In accordance with the subsidiarity principle, national legislation of the member states of the EU seeks to address domestic policy objectives, which are often different from the policy objectives in other countries. At EU level, this situation reflects negatively on the level of the freedom of movement in general and, in particular, the freedom of movement of capital, affecting major investment decisions. In the absence of harmonized rules characterizing a full banking union, banks in the EU and activities in the financial servicies sector are functioning accordingly with the vision of national priority objectives in the national rules of law, leading to widening differences between national banking systems. ${ }^{2}$

In order to analyze the impasse of the banking activities and deduce imperative measures that should be adopted in the Union for the coordination, coherence and efficiency of the banking system, the Commission has launched and introduced in March 2012 Green Paper on banking. The document states and presents the concept of "shadow banking". The Green Paper has shown that any rigid and severe banking regulation could drive a substantial part of banking activities beyond the traditional framework of activities of banking, representing the work of the shadow banking system. This concept is defined as "the system of credit intermediation that involves entities and activities outside the normal banking system." On 20 November 2012, the European Parliament adopted a resolution on the "shadow banking" system, in which the need to ensure greater transparency in the structure and activities of financial institutions is stressed. Also, the need for banking supervision is presented, in order to ensure the collection of information and knowledge from the alternative banking activities,

\footnotetext{
${ }^{1}$ Mihaela Tofan - Faculty of Economics and Business Administration, „Alexandru Ioan Cuza” University of Iasi, mtofan@uaic.ro .

${ }^{2}$ Tofan, M. (2008) Integrarea României în structurile Uniunii Monetare Europene, Publishing House C.H. Beck, Bucharest.
} 
such as repurchase agreements and securities lending. On 4 September 2013, the Commission pointed out in its Communication on the shadow banking system that transparency of the finance transactions, such as transactions in securities, repurchase agreements, securities lending and other transactions equivalent, are common and will be essential to monitor the risks associated with banking activities and services.

EU efforts to identify reform priorities for optimal regulation of the banking system continued with the establishment in March 2013 of the Inter-Service Steering Group ("ISG") with respect to structural reform banking. This working group includes representatives from the following Directorates-General of the European Commission: Competition, economy and financial services, unemployment, social security and social inclusion, justice and consumer protection, general secretary, legal services, customs and taxation and research and innovation. This working group met three times yaerly to present reports and to offer the support for the work on drawing the ferenda act relating on banking law within the EU.

The project was submitted to the Commission on 19 September 2013, which has forworded in the autumn of 2014 a proposal for a regulation to Parliament and the Council, under the name Rfegulation on measures to improve the structural strength of credit institutions in the EU.

The legal basis for its adoption is Article 114 (1) of the Treaty on the Functioning of the European Union ("TFEU"), which allows the adoption of measures for the approximation of national provisions designed to establish and strengthen the smooth functioning of the internal market. The motivation official included in the proposal for a regulation uniform rules on the functioning of banking institutions will enhance financial stability within the Union, will generate greater integration of financial markets, will facilitate orderly resolution and recovery of functional coherence, enhance cross-border provision of services and ensure the right of establishment in other Member States, in order to reduce distortions of competition and to prevent arbitrage of the regulatory framework. ${ }^{3}$

The final text was adopted in 2015 and it is expected to enter into force according to the following schedule:

- Commission adopts the regulation necessary for the implementation of key provisions until 1 January 2016;

- a list of banks covered by the derogation is published every year since mid-2016;

- a trading prohibition shall enter into force on 1 January 2017;

- The provisions on unbundling a marketing credit institutions will enter into force on 1 July 2018.

The normative proposal takes into account developments in financial markets and financial innovation, on the one hand, and the evolution of the legal framework of regulatory and supervisory institutions of the Union, on the other hand. To ensure the effective and consistent supervision and the development of the single regulatory framework in the banking sector, this proposal envisages strengthening normative influence of the European Banking Authority ("EBA") by granting wider powers in favor of this institution. In this respect, EBA shall report to the Commission and will be compulsorily consulted for the adoption of specific decisions and regulation, will be madatory involved in the process for preparation of new technical and regulatory standards.

\section{Specific objectives for the European Banking Authority in 2015}

In the EBA report for 2014 the European Banking Authority (EBA) has explicit priorities for the work of 2015, divided into three categories of priority. Most of the work in progress objectives included in the third priority group and they are in accordance with the basic objectives of the activities of this institution.

For example, monitoring the implementation of Regulation No 575/2013 is ongoing, EBA following and monitoring the steps tken by the $31^{\text {st }}$ of December 2013, when Member States have

\footnotetext{
${ }^{3}$ Andries A.M., Mutu S., Ursu S.G. (2014) Impact of institutions, financial reform and economic governance on bank performance in

"Transformations in Business \& Economics", vol. 13, issue 33C, pp. 410-429
} 
adopted and published the laws, regulations and administrative provisions necessary to comply with this regulation. The states apply these provisions from 1 January 2014.

Member States shall communicate to the Commission and EBA the main provisions of national law, which they have adopted in the field covered by the above regulation. If the documents accompanying the notification of transposition measures provided by Member States are not sufficient to fully assess the compliance of the provisions transposing certain EU regulation, the Commission may, upon request of the EBA or on its own initiative but in order to fulfill its tasks under Regulation (EU) No 1093/2010, require Member States to provide more detailed information on the transposition and implementation of these provisions.

The second priority task includes monitoring and training until 30 June 2016. The Commission, in close cooperation with EBA, shall submit a report to Parliament and the Council, together with a legislative proposal, if appropriate, concerning the provisions about remuneration, after precise analysis on this subject, taking into account international developments, in particular regarding to:

(a) the effectiveness, the implementation and the enforcement, including identification of any gaps resulting from the application of the principle of proportionality for all those provisions governing the remuneration of banking activity and banking services;

(b) the impact of the principle in Article 94 (1) (g) regarding:

(i) competitiveness and financial stability; and

(ii) any person working physically and effectively in a subsidiary established outside the EEA, for which the parent institution is established in the EEA.

Also, given the problems in connection with the prudential consolidation, EBA shall develop draft regulatory technical standards to specify the conditions under which consolidation is carried out. EBA shall submit those draft regulatory technical standards to the Commission by 31 December 2016. Among the priority objectives of the EBA activity, providing support and advice to the Commission to present a report to Parliament and the Council by 31 December 2015 are included. The report will detail the international banking market developments based on the opinion on the possibility of extending the EBA institutional framework with additional types of systemic importance within the Union, accompanied by a legislative proposal, if appropriate. To that end, EBA shall issue guidelines specifying the following concepts:

(a) the activities which are a direct extension of banking;

(b) the activities ancillary to banking;

(c) the similar activities.

The Commission may, by means of normative acts, implement decision as to whether a third country applies prudential supervisory and regulatory requirements at least equivalent to those applied in the Union. In the absence of such a decision, until the $1^{\text {st }}$ of January 2015, institutions may continue exposures to such entities as exposures to eligible institutions in the EU, considering that the relevant competent authorities have approved the third country as eligible for this treatment.

Since 2014, the EBA, in cooperation with the European Employment and Pensions Authority (EIOPA) and with the European Food Safety Markets Authority (ESMA), publishes a biennial report analyzing the extent to which the Member States refer to ratings foreign credit institutions for regulatory purposes and the measures taken by Member States to reduce such references. These reports should outline how competent authorities meet their obligations and also specify the degree of convergence in supervisory operations in this regard. Until 31 December 2014, the Commission reviewed, reported and submitted its report to the European Parliament and the Council, together with a legis lative proposal.

By 31 December 2015, the Commission shall consult the ESRB (Entertaiment Sofweare Rating Board), EBA (European Banking Authority), EIOPA (European Employment and Pensions Authority), ESMA (European Securities and Markets Authorities), and other entities and activities relevant opinion on the effectiveness of information exchange agreements under the regulations in force, both in periods of normal times and in times of stress. Also in this period, EBA shall review and report to the Committee on the implementation of the Directive and Regulation (EU) No 
575/2013 regarding the Union and Member States cooperation with third countries. This report identifies areas that require further development as regards cooperation and exchange of information. EBA report published on its website in order to provide a public consultation among all stakeholders and affected by the proposed regulation.

Also as a priority task, EBA shall develop draft regulatory technical standards to specify the assessment methodology that competent authorities should use. The conformity assessment procedure of an institution with credit risk requirements and the evaluation of the integrity of the assessment process for regular independent risk are envisaged.

EBA shall develop draft technical standards to determine implementation for all external credit assessment institutions, to establish which of the stages of credit are associated with the credit assessments relevant to international rating agencies (Group30, 2013). ${ }^{4}$ Those determinations shall be objective and consistent, and carried out in accordance with the following principles:

(a) EBA will differentiate between the relative degrees of risk expressed by each assessment;

(b) EBA consider quantitative factors, such as default and / or loss rates and the historical performance of credit assessments of each ECAI credit risk assessment in different asset classes;

(c) EBA shall consider qualitative factors such as the range of transactions assessed by the international rating agency, the methodology and the meaning of its credit assessments, in particular whether it has intended anticipated loss and first loss in euro and timely payment of interest or last payment of interest;

(d) the EBA will seek to ensure that securitization positions to which the same risk weight is applied on the basis of assessments by external credit assessment institutions, when the institution is subject to equivalent degrees of credit risk. EBA consider amending its judgment agreed standard credit qualityş a particular credit assessment shall be associated, as appropriate.

EBA submitted these draft technical standards implementation on 1 July 2014 and develop draft regulatory technical standards to specify the following:

- Assessment methodology under which competent authorities permit institutions to use internal models;

- Working conditions in which procedures can be covered by the internal model

\section{Strategic objectives for the EU banking regulations}

President Mario Draghi spoke about the mission of the ECB's inflation target, which requires today, ironically, the need to produce inflation. Inflation targeting turns to creating inflation. ${ }^{5}$ As stated by the G30, regulatory oversight and supervision are different concepts and high quality has a direct influence on financial stability. ${ }^{6}$ Recently, banking regulations have been adopted to strengthen financial institutions' capacity to respond to crises of global dimensions and to any particular problems, no matter as "softer" as they were described (organizational supervisory issues or cultural organizations).

There are four mandatory actions to improve regulations on banking supervision and monitoring at EU level in order to ensure financial stability: ${ }^{7}$

1. the regulations for management committees should strengthen supervision / monitoring and relations based on mutual and clear obligation to inform and consult each other in line with the specific business vulnerabilities and

\footnotetext{
4 A New Paradigm. Financial Institution Boards and Supervisors, Washington D.C. (2013), web page. Retrived from http://www.group30.org/images/PDF/Banking_Supervision_CG.pdf, last consulted on November 1, 2015.

${ }^{5}$ Daianu, D., (2015). Marele impas in Europa. Ce poate face Romania?, Polirom, Iasi.

${ }^{6}$ Roman, A. (2012) The Euro area sovereign debt crisis and the role of ECB's monetary policy in "Procedia Economics and Finance, Emerging Markets Queries in Finance and Business", Volume 3.

${ }^{7}$ EBA releases work plans for 2015 (October 2014), web page. Retrived from http://www.eba.europa.eu/-/eba-releases-work-plansfor-2015, last consulted on November 1, 2015.
} 
effectiveness of leadership / governance. It is obvious that a compulsory two-way communication will generate efficiency.

2. The presidents' powers and duties of management structures should be clearly outlined in the legal rules in force, as a guarantee for efficiency and productivity of surveillance activity.

3. The power control and supervisory staff and management objectives set out should be clearly separated by stating explicit that the complementarities of their activities are fundamental.

4. Governments / national executives must ensure that supervision in the banking sector means more than checking compliance with the rules of law in force, demanding appropriate means including the provision of sufficient financial and human resources.

For any financial and banking institution which proves to the satisfaction of the competent authority to monitor and control that its lending activities do not jeopardize the financial stability of the Union, taking into account the express provision of EU regulation now in the Regulation, the competent authority may decide not to require the taking of precautions such as separation.

Article 10 (2) of the Regulation establishes that the proposal to the competent authority for monitoring and control in order to single out particular trading activities may be considered if it is assumed that the activity in question threatens the financial stability of the bank or the Union, and reports breach of any of the objectives proposed in the Regulation. The competent authority should consult EBA before taking decisions referred to in Article 10 and should inform EBA of the final decision.

\section{Conclusions}

The proposed regulation for banking in the EU, the European Commission launched in autumn 2014 the regulation providing the legal framework for adopting measures in order to standardize national provisions concerning rules on banks' structures.

EU Regulation from 2014 for banking sector is characterized by the opportunity given to competent authorities to monitor the activity of credit institutions and to take the necessary measures, including the ability to require separation when trading activities of banks and risks are assessed and objectively classified as hazardous by exceeding certain levels of risk. The normative act relates primarily to certain conditions on the prudential trading activities, but is not limited to, being equally targeted actions to expand market share, investments and risky operations of sponsorship and marketing, in certain circumstances.

The main objective of the new regulations in the EU banking law is to identify rules that could cause a substantial harmonization of banking activities beyond traditional banking activities, in order to shape a legal framework for single bank union.

\section{Bibliography}

1. Andries A.M., Mutu S., Ursu S.G. (2014) Impact of institutions, financial reform and economic governance on bank performance, in "Transformations in Business \& Economics", vol. 13, issue 33C

2. Daianu, D., (2015). Marele impas in Europa. Ce poate face Romania?, Polirom, Iasi

3. Roman, A. (2012) The Euro area sovereign debt crisis and the role of ECB's monetary policy in "Procedia Economics and Finance, Emerging Markets Queries in Finance and Business", Volume 3

4. Tofan, M. (2008) Integrarea României în structurile Uniunii Monetare Europene, Publishing House C.H. Beck, Bucharest.

5. A New Paradigm. Financial Institution Boards and Supervisors, Washington D.C. (2013), web page. Retrived from http://www.group30.org/images/PDF/Banking_Supervision_CG.pdf, last consulted on November 1, 2015.

6. EBA releases work plans for 2015 (October 2014), web page. Retrived from http://www.eba.europa.eu/-/ebareleases-work-plans-for-2015, last consulted on November 1, 2015. 